\title{
Travel Narratives and Orientalism: Montagu and Montesquieu
}

'Tis a particular pleasure to me here to read the voyages to the Levant, which are generally so far remov'd from Truth and so full of Absurditys I am very well diverted with 'em. They never fail giving you an Account of the Women, which 'tis certain they never saw, and talking very wisely of the Genius of the Men, into whose Company they are never admitted, and very often describe Mosques, which they dare not peep into.

-Lady Mary Wortley Montagu, The Turkish Embassy Letters

(1717-1718)

Comment as-tu pensé que je fusse assez crédule pour m'imaginer que je ne fusse dans le monde que pour adorer tes caprices? . . . Non: j'ai pu vivre dans la servitude; mais j'ai toujurs été libre: j'ai reformé tes lois sur celles de la nature; et mon esprit s'est toujours tenu dans l'indépendance.

[How could you think me so credulous that you imagined I was in the world only to worship your caprices? . . . No: I may have lived in servitude, but I have always been free. I have reformed your laws according to the laws of nature, and my mind has always remained independent.]

-Roxane à Usbek, in Montesquieu Lettres persanes (1721)

Eighteenth-century portraits of the oriental world as an exotic, uncivilized counterpart of Europe were crucial enunciations of the discourses that produced representations of the European world as knowing, stable, and powerful. Travel literature performed these acts of symbolization for French and English culture; by figuring travelers 
in foreign lands encountering strange and disorienting customs and practices, the trope of travel allegorized the problems of maintaining cultural institutions amidst challenging othernesses, of establishing cultural standards and norms in the context of heterogeneity and difference. In this way not only did the literary theme of travel serve to express the eighteenth-century colonial preoccupation with land and empire, but also travel as a representation of territorial ambition became a predominant discursive means for managing a national culture's concern with internal social differences and change. In England these social challenges to the status quo included religious dissent, growing parliamentary control, budding industry, and a growing working class; in France the ancien régime faced nonaristocratic dissent, republican challenges to the monarchy, and peasant revolts. In other words, the utopian geographic expansion implied by travel literature addressed national anxieties about maintaining hegemony in an age of rapidly changing boundaries and territories. Yet it also regulated the social quarrels besetting the old regimes of the period by transfiguring internal challenges to the social order into fantasies of external otherness.

Lady Mary Wortley Montagu's Turkish Embassy Letters (1717-1718) explicitly challenge the received representations of Turkish society furnished by the seventeenth-century travel writers who preceded her. Although she writes in that tradition of letters about traveling in Turkey, Montagu distinctly sets herself apart from that tradition by criticizing the representations of women, marriage, sexuality, and customs in the travel accounts of Robert Withers, George Sandys, John Covel, Jean Dumont, and Aaron Hill. In redressing many of what she insists are the misconceptions and inaccurate representations of Turkish women propagated by these male travel writers, Montagu reports how, as a woman, she is permitted greater access to Turkish female society, and claims that her difference from these earlier writers may in fact be due to her being a woman. In this sense Montagu's position with regard to English travel writing is paradoxical, or multivalent, in a manner that the earlier travelers' accounts are not. On the one hand, some of her descriptions-written as they are from her position as wife of a British ambassador-resonate with traditional occidental imaginings of the Orient as exotic, ornate, and mysterious, imaginary qualities fundamental to eighteenth-century Anglo-Turkish relations. 
At the same time, unlike the male travel writers before her, she employs comparisons that generally liken the conditions, character, and opportunities of European women to those of Turkish women. Montagu's identification with Turkish female society invokes an emergent feminist discourse that speaks of common experiences among women of different societies; in addition, Montagu's identification with the wives and mistresses of Turkish dignitaries also makes use of the existing discourse of class distinction, and an established identity of aristocratic privilege across cultures. Montagu's representations of Turkey in the Letters thus employ both the rhetoric of identification, most frequently in her descriptions of Turkish court women, and the rhetoric of differentiation with regard to other aspects of Turkish society in general. Indeed, Montagu's observations often invoke the rhetoric of both similarity and difference; that is, in the very act of likening Turkish and English women, Montague relies on and reiterates an established cultural attitude that differentiates Orient and Occident, that constitutes them as opposites. ${ }^{1}$ The paradoxes of the British ambassador's wife's relation to Turkish women call our attention to the sense in which in the eighteenth century, English orientalism is not monochromatically figured through an opposition of Occident and Orient but figures itself through a variety of other differentiating discourses. The Turkish Embassy Letters provide a particular example of orientalist representations overlapping with rhetorics of gender and class, and of orientalism generated by differently genderdetermined and class-determined positions. ${ }^{2}$

\footnotetext{
II is interesting to note the etymology of the term Orient, for it bears on the discussion of eighteenth-century travel literature, the geographic figuration of otherness, as one of the earlier rhetorical frameworks of orientalist literature. From the Latin oriens, meaning "rising," "rising sun," or "east," the term came to mean largely all that is not the Occident, or occidens-"quarter of the setting sun" - from the infinitive occidere, "to fall down," "to set." If the Occident was the location of that geographic place on the horizon where the sun sets, then the Orient was the opposite place where the sun rises. But through a variety of social and historical turns, what began as a geographic topos became an ideological one; or to put this another way, ideological values became figured through a geographic and etymological binary opposition. In this sense, British and French knowledge of the world was represented in terms of this dualistic vision: West or East. Many other categories of definition could then be produced and ascribed according to this binary scheme: the West was the Christian land, the East was the space of infidels, heretics, pagans, and so forth.

${ }^{2}$ There are examples of heterogeneity among other women travel writers. In "Victorian Travel Writings," Genre 22, no. 2 (Summer 1987): 189-207, Susan Morgan exam-
} 
In a rather different manner, discourses of gender, class, and orientalism also intersect in a text by a French contemporary of Montagu's, Montesquieu's Lettres persanes (1721). Like the Turkish Embassy Letters, Montesquieu's text emerges at a moment in which the discourse of orientalism is alternately destabilized, accommodated, and reinforced by a constellation of other discourses: one that constitutes women as romantic and sexual Others, as well as an emergent discourse about female independence; and a discourse about class distinction and privilege, as well as an emergent discourse of class equality. But in Montesquieu's novel, the fictional as well as the epistolary qualities work to multiply the conflicts, contradictions, and collusions between orientalism and other intersecting inscriptions. The Lettres persanes may conform to a traditional orientalist structure that opposes the tyranny and licentiousness of Persia to rational, civilized France. But at the same time, its ironic inversion posing the drama of Persians traveling in France and their failing rule over the harem as an allegory for French problems of rule simultaneously calls that orientalist opposition into question. In addition, the Persian wives, female slaves, and eunuchs figure significantly not merely as ornaments in the exotic harem but as "gendered" and "classed" representations; when the wives and female slaves revolt against the eunuchs and the despot, the novel's harem plot crosses orientalism with the concurrent discourses about class hierarchy and gender relations. In this sense, the orientalist opposition of France and Persia is destabilized by the ironic inversions of the two cultures and also by the novel's competing representations of gender and class struggles. The demise of the oriental despot is a plot that makes use of a sexual drama of male domination and female submission, as well as a drama of class conflicts between despot, wives, eunuchs, and female slaves. Ultimately, if we read the relationship of the master and the wives as a gendered representation of the French problem of colonial rule, or as an emblem of the relationship of unequal power between Occident and Orient

ines the travel writings of British women in Southeast Asia; she points out that these women writers are exceptions within the tradition of what has been monolithically termed orientalism. The orientalism of Edward Said, Morgan argues, is predominantly a male tradition, and predominantly about the Middle East. The writings of these British women writers in Southeast Asia are exceptions to this tradition, Morgan observes, and contain very different representations of the Orient, and very marked sympathy, in particular with the female population of these countries. 
enunciated by the traditional orientalist frame, then the triumph of the wives and female slaves over Usbek's authority at the end of the Lettres provides a final narrative challenge to orientalism.

Even as we accept the general premise that orientalism is a discourse through which European institutions-literary, political, and economic - are able to generate a consistent notion of the Occident while constituting and subordinating its oriental Other, orientalist situations expressed in texts such as Montagu's and Montesquieu's illustrate that other social concerns may displace, be displaced by, or collaborate with orientalism. In other words, not only are orientalisms produced by distinct cultural and historical factors in different periods, but also the cases of Montagu and Montesquieu demonstrate that individual orientalist situations are themselves neither uniform nor without contradictions. The competing narratives of culture, class, and gender in Montagu's Turkish Embassy Letters serve as one example of the variety of representational forces that may complicate a particular orientalist situation. As an emblem of heterogeneity itself, Montagu's text diverges from earlier British travel writers' accounts of Turkey, and constitutes a contrast to the types of intersections to be found in Montesquieu's Lettres persanes, underscoring further that eighteenthcentury orientalism was by no means monolithic. In focusing this chapter on two examples of early-eighteenth-century epistolary travel literature, one British and one French, I aim to explore several different narrative constructions of the relation between occidental and oriental worlds produced in the same period in order to suggest the considerable heterogeneity both between and within culturally specific orientalisms.

Thus, this chapter is concerned with the moments at which the production and the management of sameness and difference are not limited to the figuration of cultural oppositions but include representations of contrary genders and classes, or whose oriental figurations are heterogeneous by virtue of being generated from differently genderand class-determined positions in culture. In both the British and the French examples, orientalist inscription is not a discrete operation; it comes about as the result of a multiplicity of discursive formations, dominant and emergent, conflicting and combining in the cultural fields of struggle that produce travel writings. The variety of such discourses in the eighteenth century is not limited to those that dif- 
ferentiate masculinity and femininity, or that separate and distinguish social classes. Along with inscriptions of mastery and slavery, racial differences, and disease and health, one discovers a spectrum of uneven representations operating both outside and within this particular orientalist terrain. I have said that the unresolved multiplicity of representational forces emphasizes how orientalism, rather than existing as an isolated, univocal discourse, takes place in a plural and mutable field of varied positions and representational practices. When one grasps this plurality and mutability as the given condition of an orientalist situation, or any situation of cultural domination, then one also identifies the destabilized moments where resistance begins and transformation becomes possible.

\section{"So many Beautys as are under our Protection here": The Turkish Embassy Letters}

Lady Mary Wortley Montagu had the occasion to spend several years in Turkey beginning in 1717, when her husband, Edward Wortley Montagu, was called to serve as British ambassador there. Within her own lifetime, her literary and intellectual distinction was recognized by many writers, including Alexander Pope and his circle, and she became quite famous when the Turkish Embassy Letters were published the year after her death in $1763 .{ }^{3}$ Montagu's other accomplish-

\footnotetext{
${ }^{3}$ Robert Halsband, editor of the Complete Letters, and coeditor of Essays and Poems, suggests that the manuscript of the Turkish Embassy Letters was composed from copies of letters Lady Mary had written from Turkey, and that they may have been meant for publication as a travel memoir. Halsband writes: "They are not the actual letters she sent to her friends and relations; they are, instead, a compilation of pseudo-letters, dated, and addressed to people either named or nameless. Although they are clearly an accurate record of her experiences and observations during her two-year sojourn abroad, we may still wonder to what extent they are based on real letters. Are they perhaps a travel-memoir in the form of letters (a literary genre popular since the Renaissance)?" Introduction to Complete Letters, pp. xiv-xv.

Before she died, Lady Mary gave a copy of the manuscript to Benjamin Sowden, implying that it had been her wish that they should eventually be published. See "Biographical Anecdotes," in Lady Mary Wortley Montagu, Essaysand Poems, ed. Robert Halsband and Isobel Grundy (OxfOrd: Clarendon Press, 1977), pp. 32-33. Halsband concludes in his introduction to the Complete Letters that "it is certain that she intended them to be published, though not in her lifetime" (p, xvii).
} 
ments include her essays in which she argued persuasively for a change in the treatment of women in English society in favor of recognizing women's social and intellectual virtues, as well as her significant contribution toward introducing the smallpox vaccine into England after her return from Turkey. ${ }^{4}$

The diplomatic presence of the Montagus in Turkey was warranted by a British commercial relationship with the Ottoman court that had begun in the late sixteenth century under Queen Elizabeth I. England imported silks, spices, cotton, soaps, oils, and carpets, while Turkey received armaments and tin. The Levant Company, founded in 1581, was one of England's most important early commercial ventures, established at the time when England was also beginning its longstanding colonial relationships with India and Africa, in the form of the East India Company and the Royal African Company. These merchant companies rose to great prominence during the seventeenth century. As a result of the Navigation Act of 1660, which resulted in England's commercial monopoly of overseas trade and transportation of goods, ${ }^{5}$

${ }^{4}$ Montagu articulates her position with regard to the sexes and declares her sympathy with the developing feminist movement in an installment of The Nonsense of CommonSense, a weekly newspaper. In an essay dated January 24,1738 , Montagu responds to an essay written by Lord Chesterfield in which he advised women on how to resist various temptations, especially that of succumbing to a love affair. Montagu refutes his assumption that women must resist seduction by "filling up their time with all sort of other triffles: in short he recommends to them, Gosiping, Scandal, Lying, and a whole troop of Follys ... a as the only preservatives for their Virtue" Montagu, Essays and Poems, p. 131. She suggests instead "Reason or Refflection," as well as treating women "with more dignity" (p. 131).

See "Letter to Sarah Chiswell" on the subject of innoculation, Complete Letters, pp. 337-40; and "A Plain Account of the Innoculating of the Small Pox by a Turkey Merchant," Essays, pp. 95-97. Indeed, we might consider the vaccine a metaphor for crosscultural experience. That is, Lady Mary proposed that "the best sort of the Small Pox" be introduced in small quantity-"the point of the Needle takes as much of the matter as will lye upon it" - in order to inoculate individuals against more serious fatal infection, just as twentieth-century anthropologists would later advocate some virtue in the experience of "going native" to learn more about the cultures they studied.

${ }^{5}$ Christopher Hill, The Century of Revolution, 1603-1714 (New York: Norton, 1961), esp. chaps. 13 and 17, argues that the main point of the Navigation Acts was a "deliberate policy of developing the production, and monopolising the export, of colonial commodities like tobacco, sugar, cotton, dye-woods." On the labor of the colonists, Hill cites Charles Davenant, On the Plantation Trade, as stating that it was probably six times more profitable than labor at home, owing to slavery. "The Acts created monopoly conditions of trade with the colonies, and so increased the profits of English merchants. They mark a decisive turning-point in England's economic history" (p. 181). 
and the free trade policies-affecting imported goods, re-exported products, and the slave trade-which followed the Revolution of 1688, exports and imports between England and its foreign markets tripled. By the early eighteenth century, English foreign policy decisions were being made largely to accommodate England's trading and colonial interests.

Not only did the merchant companies of the late seventeenth century enjoy the patronage of the government, but these companies, essential instruments in defeating other European trade efforts (such as Spanish, Dutch, and French commerce), were given substantial powers and privileges, including judicial and administrative power over competitors and foreign governments, as well as over the colonies themselves. The English travel accounts that accompanied the deepening of Anglo-Turkish diplomatic and commercial ties in this period form an integral part of the discourse about the colonies that depicted foreign and colonial cultures as possessing exceedingly different-and, by implication, less civilized-customs, religions, and practices from those of European society. These accounts played a leading role in establishing the terms of the relationship between European and colonial cultures. The portraits of Turkish and Middle Eastern culture as alternately violent and barbaric, slovenly and lascivious, or grotesque and incomprehensible supported and permitted an ideology that justified the cultural subordination of the foreign and colonial cultures from which profits were being extracted in the form of materials and goods, labor, and consumer markets. Included in this travel literature are accounts such as Robert Withers, A Description of the Grand Signor's Seraglio (1650); George Sandys, Sandys Travailes (1658); John Covel, Early Voyages and Travels in the Levant (1670); Jean Dumont A New Voyage to the Levant (1696); Aaron Hill, A Full and Just

England's monopolization of the overseas trade marked the transition to a new type of economy. Slaves from West Africa were brought to England and Jamaica by English manufacturers. Refining and finishing industries sprang up in London and elsewhere for the home market and for reexport. Between 1660 and 1700, whereas manufactured goods (other than cloth) exported to England expanded by 18 percent, exports to the colonies expanded by over 200 percent. Hill suggests that nineteenth-century industrialism might well have been impossible without the Navigation Acts. Colonial trade prepared for the industrial revolution, just as the political revolution had made possible the use of full state power for the capture and retention of monopoly colonial trade. 
Account of the Present State of the Ottoman Empire (1709); as well as Montagu's Turkish Embassy Letters. The observations of these writers are not uniform but differ in rhetoric and style of presentation, as well as in the sorts of subjects that are discussed. It is in this tradition of travel writing that Lady Mary Wortley Montagu distinguishes herself, and to this tradition that she addresses many of her criticisms.

Robert Withers's Description of the Grand Signor's Seraglio attempts to establish the traveler's credibility by claiming that he had "procured admittance to the Seraglio, and by continuance many years in those parts, had time and opportunity to perfect his observations." Later in the text, however, he divulges his lack of authority by stating that "no white man can visit amongst the women." Despite this lack of experience, Withers's account is filled with the melodramatic caricatures of exotic sexuality and barbarism in the seraglio for which orientalism is so famous: the deprivation and brutalization of the Turkish women, the cruelty of the eunuchs, the ugliness of the slave girls-all of which is pointedly contradicted by Montagu in her letters. For example, Withers details a colorfully mythologized ritual in which the king selects his mistress for the evening from a display of women by dropping a handkerchief into the hand of the selected one. Montagu targets Withers's description of the ritual as an example of "the common Voyage-writers who are very fond of speaking of what they don't know" and refutes it as absolutely fictitious. ${ }^{6}$

Like Withers's account, which contains an admission of his lack of knowledge, Jean Dumont's New Voyage to the Levant is similarly marked: "We went to the Grand Signor's seraglio which I cannot describe exactly, since I was not suffer'd to go further than the Second Court."7 Uninhibited, however, Dumont continues to extrapolate from what he does not know: "The Sultan's wives are lodg' $\mathrm{d}$ in a Third Seraglio. ... I need not tell you with what severity they are guarded by the white and black Eunuchs, who never permit 'em to enjoy the least Shadow of Liberty" (p. 167). Dumont, too, records more tales of bizarre and exotic rituals, cataloguing the "lazy manner of living," con-

${ }^{6}$ Robert Withers, A Description of the Grand Signor's Seraglio or Turkish Emperor's Court (London, 1650), p. 110. For Montagu, see letter to Lady Mar, March 10, 1718, in Complete Letters, p. 383: "The Sultana . . . assur'd me that the story of the Sultan's throwing a Handkerchief is altogether fabulous."

JJean Dumont, A New Voyage to the Levant (London, 1696), p. 165. 
cubinage, and the persecution of women. Of Turkish men he writes: "Contented with their Lot, they sit whole Days on a Sopha, without any other Occupation than drinking Coffee, smoaking Tobacco, or caressing their wives: So that their whole Life is a continual Revolution of Eating, Drinking and Sleeping, intermixt with some dull Recreations" (p. 262). On the manners and customs of the Turks, he concludes: "I found that what they call Strength of Mind, Constancy or Solidity, is at the bottom nothing else but a pure Insensibility and a Weakness that is altogether inexcusable in any reasonable creature" (p. 261).

One of Dumont's chief condemnations of Turkish men is his claim that they enslave their women. ${ }^{8}$ But his representation of the enslavement of women functions as an emblem for the "uncivilized" practices of the oriental rather than as a critique of social or cultural institutions that subordinate women. This is most evident in Dumont's portrait of Turkish marriage, in which a thinly veiled misogyny is revealed in a supposedly humorous barb against European women: "The men may have four Wives and may have twenty Concubines. . . . Those who are weary of their Wives may turn 'em away when they please, paying their Dowry. What d'ye think, Sir, of this Custom? Is it not very pleasant and commodious? 'Tis Pity that we have not such a Fashion in Christendom; for if we had, I believe we shou'd see many fatal knot unty'd" (p. 267). Dumont's quip-“'Is it not very pleasant and commodious?"- does not merely condemn Turkish men; it also demonstrates a clear wish to subordinate European women. In constructing the enslavement of women as a sign of Turkish barbarism, Dumont differentiates from it the propriety of European marriage, and concomitantly makes the European woman a sign of "civilized" culture. Dumont's humor is built on an expressed envy of the license to exploit women; the statement suggests that the theme of female enslavement is a male fantasy that emerges from the context of European sexual relations rather than from any knowledge of Turkish arrangements. A third concurrent aspect of Dumont's misogyny is the objectification of Turkish women; in his account they are entirely sexual: "The Turkish Women are the most charming Creatures in the World: they seem to be

\footnotetext{
${ }^{8 \prime}$ There is no slavery equal to that of the Turkish Women; for a Servant may live twenty years in a Family without seeing the Face of his Mistress," writes Dumont, A New Voyage, p. 268.
} 
made for Love; their Actions, Gestures, Discourse and Looks are all Amorous" (p. 273). In this compartmentalization he divides womanhood into willful European women and willing Turkish women. This opposition reduces women to polar caricatures of male fear and desire, and constructs impediments to a discourse suggesting that some female experiences might be shared even across cultural differences. Montagu decisively refutes this constructed opposition in her Turkish Embassy Letters.

As a woman, Montagu was invited into Turkish female society, and as a result she was in a particularly good position to contradict the statements of her predecessors. Her letters feature, among other observations about the local culture, descriptions of pleasant occasions when she called on the wives of Turkish dignitaries or was invited to dine at the Turkish court. One particular letter to her sister (to Lady Mar, April 1, 1717) contains an elaborate representation and analysis of life among Turkish women. It is worth giving some attention to this letter, for it illustrates most aptly the ways in which Montagu's attitudes toward Turkish women opposed those of the seventeenth-century male travel writers, and also underscores what I described earlier as Montagu's multivalent position as an aristocratic English woman.

The paradoxes of Montagu's position are borne out in her modes of comparison, which simultaneously employ the rhetorics of identification and of differentiation in relation to Turkish women. The identification that Montagu articulates between herself and Turkish women is established primarily by means of an analogy of gender, but it is also supported by an implicit rhetoric that is based on, and enunciates, an identity of social class. Montagu's comparisons with Turkish women are confined to women of only the very highest social class in Adrianople. Her use of identities of gender and class serve different purposes, and intersect with the discourse of orientalism in unlike ways. Montagu's rhetorical assertions of identity among women are both discursively antagonistic to, and supportive of, the differentiating rhetorics of culture that characterize orientalism; even the rhetoric that invokes a class identity is, at the same time, built on a structure of class opposition that distinguishes aristocrats and commoners, a rhetoric of differentiation that of ten overlaps with and reinforces the oppositional rhetorics of orientalism.

Montagu's letter to Lady Mar begins with a detailed account of her 
current practice of dressing in the Turkish mode, stating that the purpose of her "full and true Relation of the Noveltys of this Place" is to awaken the "gratitude" of Lady Mar in order to urge her to write more news about England-to "let me into more particulars" about "your side of the Globe." Thus, the letter's opening establishes England and Turkey as being separated by time, distance, and culture, and this opposition is continually both posited and effaced throughout the letter. Montagu writes to Lady Mar:

I am now in my Turkish Habit, thô I beleive you would be of my Opinion that 'tis admirably becoming. I intend to send you my Picture; in the mean time accept of it here.

The first peice of my dresse is a pair of drawers, very full, that reach to my shoes and conceal the legs more modestly than your Petticoats. They are of a thin rose colour damask brocaded with silver flowers, my shoes of white kid Leather embroider'd with Gold. Over this hangs my Smock of fine white silk Gause edg'd with Embroidery. . . . The Curdée is a loose Robe they throw off or put on according to the Weather, being of rich Brocade (mine is green and Gold) either lin'd with Ermine or Sables. [ . . ] On the other side of the head the Hair is laid flat, and here the Ladys are at Liberty to shew their fancys, some putting Flowers, others a plume of Heron's feathers, and in short, what they please, but the most general fashion is a large Bouquet of Jewels. (Complete Letters, pp. 32627)

The long passage describing her Turkish garments expresses two apparently, though not necessarily, contradictory impulses. On the one hand, Montagu provides an inventory of the fabrics, embroideries, brocades, and precious stones that she has become accustomed to wearing; the long description and analysis exhibits her familiarity with and knowledge of the Turkish female style, and the use of possessives_-"my shoes," "my Smock" - rhetorically identifies her position with that of Turkish women. Indeed, the "Picture" of herself in Turkish dress to which she refers in the letter is an emblem of her high degree of assimilation into Turkish culture-a representation of a desired virtual synonymy or identity between herself and Turkish women - of which she is apparently quite proud. ${ }^{9}$ On the other hand,

\footnotetext{
${ }^{9}$ Montagu prided herself on her immersion in Turkish culture; she learned the language, and, emblematically, had herself painted in Turkish dress. See this portrait, attributed to Charles Philips, in Complete Letters, pl. 5.
} 
phrases punctuated by the comparative possessive your refer to English women's customs: "your side of the Globe," "more modestly than your Petticoats." These phrases rhetorically reinforce Montagu's Turkish context and her distance from English culture. A similar separation and opposition of location is stated in the distinction between "here" and "there": "and here the Ladys are at Liberty to shew their fancys." In other words, the rhetoric of similitude through which Montagu displays her intimate identification with Turkish women's culture relies simultaneously on stated and implied differentiations; the rhetorical act of likening herself to Turkish women ironically recalls an established separation of Occident and Orient.

Proceeding from the description of her own hair styled in the Turkish manner, Montagu goes on to admire the beautiful hair, complexion, and eyes of the Turkish women. The juxtaposition of the description of the "Turkish Ladys" with Montagu's description of herself in Turkish dress creates a structural equivalence between her position and that of Turkish women that reiterates Montagu's initial gesture of identification. This gesture implies not only an equivalence of gender but also an equivalence between the two court societies, stressing the similarity between these women's social rank and her own. Montagu rhetorically substitutes herself for a Turkish woman; the posited interchangeability enunciates an equivalence of both gender and class status. Although English and Turkish women are presented as structurally interchangeable in the juxtaposition, however, the language of the passage about hair contains superlatives that elevate the beauty of Turkish women with regard to English beauty. She writes: "I never saw in my Life so many fine heads of hair . . . every Beauty is more common here than with us. 'Tiz surprizing to see a young Woman that is not very handsome. . . . I can assure you with great Truth that the Court of England (thô I beleive it the fairest in Christendom) cannot shew so many Beautys as are under our Protection here" (p. 327). Here it is as if Montagu employs a rhetoric of differentiation-"Beauty is more common here than with us" - in order to convey a parity or equality between English and Turkish women. That is, an assertion of Turkish women's superiority in the area of physical beauty serves as an intervention that targets and challenges the implicit orientalist subordination of the Turkish to the English. Thus, in the phrase "under our Protection here," Montagu cannot avoid referring to the subor- 
dinating colonial arrangements that locate and justify her presence as part of a British diplomatic entourage in Turkey.

In the next section of the letter the argument for the advantage or superiority of Turkish women with regard to English women is even more explicitly utilized as an intervention against traditional orientalism. In these passages Montagu directly refutes the earlier travel writers' constructed accusation that Turkish women are enslaved:

As to their Morality or Good Conduct . . ' 'tis just as 'tis with you, and the Turkish Ladys don't commit one Sin the less for not being Christians. Now I am a little acquainted with their ways, I cannot forbear admiring either the exemplary discretion or extreme Stupidity of all the writers that have given accounts of 'em. Tis very easy to see they have more Liberty than we have, no Woman of what rank so ever being permitted to go in the streets without 2 muslims, one that covers her face all but her Eyes and another that hides the whole dress of her head. . . .

This perpetual Masquerade gives them entire Liberty of following their Inclinations without danger of Discovery. . . . Neither have they much to apprehend from the resentment of their Husbands, those Ladys that are rich having all their money in their own hands, which they take with 'em upon a divorce with an addition which he is oblig' $\mathrm{d}$ to give 'em. Upon the Whole, I look upon the Turkish Women as the only free people in the Empire. . . .

'Tis true their Law permits them 4 Wives, but there is no Instance of a Man of Quality that makes use of this Liberty, or of a Woman of Rank that would suffer it. When a Husband happens to be inconstant (as those things will happen) he keeps his mistrisse in a House apart and visits her as privately as he can, just as 'tis with you. (pp. 327-329; emphasis added)

Montagu cites the same cultural customs mentioned by the travel writers-that women go veiled in public, that they are guarded by servants-to support an entirely opposite argument. Rather than contending that Turkish women are enslaved, Montagu asserts that, owing to being veiled, they are able to enjoy even more liberties than English women. Montagu's statement that "Upon the Whole, I look upon the Turkish Women as the only free people in the Empire" is significant because of the ways in which it challenges several discourses that inform seventeenth-century male travel writing. In one respect, her statement forcefully intervenes in the orientalist discourse that proposes the enslavement of Turkish women as a sign for oriental 
barbarism. Her claim further implies that Turkish women are freer than English women, a statement that directly contradicts the antifemale discourse that is equally present in the travel writing, a discourse typified by Dumont's comment on the alleged Turkish custom of enslaving women ("Is it not very pleasant and commodious? 'Tis Pity that we have not such a Fashion in Christendom"). Dumont's colonialist trope of the enslaved Turkish woman is not only an orientalist construction used to condemn Turkish society as uncivilized, but also a displacement of European misogyny which disguises its European character by figuring women's subjugation in an oriental context. Montagu's assertion of the freedom of Turkish women heartily objects to the construction of women in orientalist myths, and simultaneously contradicts the exaggeration of European women's freedoms implied by Dumont's account. It is Montagu's opinion elsewhere in her writings that women in European society must be accorded more respect, more opportunities, and greater financial independence before they can even be considered as beginning to enjoy equality with men. Montagu's idealization of the liberty of Turkish women, however, which targets and challenges the male orientalist attack on European women, must also be scrutinized for its bias; her claim that Turkish women are "the only free people in the Empire" misrepresents and appropriates Turkish female experience for the purpose of defending English feminism.

The characterization of Turkish women's comportment as a "Masquerade" also assimilates Turkish culture to English terms and modes of cultural expression. The term has a particular meaning in the eighteenth-century British social and moral context. As Terry Castle explains, the masquerade was directly associated with carnivalesque practices that overturned traditional social structures, and these socially sanctioned disguises connoted sexual license as well as defiance of social and class hierarchies. ${ }^{10}$ In the English concept of masquerade, disguises afforded an anonymity that permitted sexual and social promiscuity: masked ladies could take lovers, courtiers could pretend to be peasants, or an aristocratic lady might disguise herself as a servant girl to take a young lover from a more common class. For Montagu to call the Turkish woman's veil a masquerade is to transfer

10See Terry Castle, Masquerade and Civilisation (Stanford: Stanford University Press, 1986). 
these specifically English associations to Turkish women's society, to interpret the Turkish context by means of an ideologically charged English classification, and to attribute to Turkish women a powerful ability to subvert the traditional cultural systems of sexuality and class relations. In this sense the use of the term masquerade does not merely confirm Montagu's identification with Turkish women; it also involves some appropriation of their position for the purpose of intervening in the male tradition of travel writing about the Orient. Implying that Turkish women are the site of a variety of subversive actions, that veiled they are protected by an anonymity that allows them sexual and social license, Montagu makes of Turkish women a sign of liberty and freedom in a manner not unlike Dumont's earlier rendering of Turkish women as a sign of enslavement and barbarism.

Montagu's paradoxical use of the rhetoric of likeness and difference challenges the established logic of orientalist travel writing in a variety of ways. Her letter to Lady Mar ends with explicit criticisms directed at the "voyage Writers" who had previously written about Turkey: "Thus you see, dear Sister, the manners of Mankind doe not differ so widely as our voyage Writers would make us beleive" (p. 330; emphasis added). Montagu notes, as I have remarked in the brief discussion of Withers and Dumont, that the seventeenth-century travel writers privileged a logic of differentiation in their figurations of Turkey, and that, in particular, their construction of the Orient as "different" hinged on an invention of Turkish customs regarding women as dramatically opposing English ones. Thus, when Montagu repeatedly likens English and Turkish women, her rhetoric of similitude directly contradicts the logic of difference that characterizes the observations of the male travel writers. At the same time, to a certain degree the rhetoric of identification through which Montagu displays her knowledge of Turkish women's culture inevitably restates an orientalist topos of differentiation in order to target it, ironically recalling the established separation of Occident and Orient. In this sense, on the level of rhetoric Montagu's text employs competing and fluctuating logics of similarity and difference. The use of the rhetoric of difference places Montagu's text in relation to a discourse of orientalism, whereas the rhetoric of identification expresses the critical distance of the text from orientalism, marking it as heterogeneous, divergent, and dissenting.

Other letters, such as to Lady__ April 1, 1717, describing a visit 
to the women's baths, ${ }^{11}$ echo the praise of Turkish women's beauty, and extends the description of their excellence to the areas of poise, manners, and etiquette.

I was in my travelling Habit, which is a rideing dress, and certainly appear'd very extraordinary to them, yet there was not one of 'em that shew'd the least surprize or impertinent Curiosity, but receiv'd me with all the obliging civillity possible. I know no European Court where the Ladys would have behav'd themselves in so polite a manner to a stranger. ...

The first sofas were cover'd with Cushions and rich Carpets, on which sat the Ladys, and on the 2nd their slaves behind 'em, but without any distinction of rank by their dress, all being in the state of nature, that is, in plain English, stark naked, without any Beauty or deffect conceal'd, yet there was not the least wanton smile or immodest Gesture among 'em. They Walk' $d$ and mov'd with the same majestic Grace which Milton describes of our General Mother. (Complete Letters, p. 313)

Montagu compares the manners of the "Ladys" at the Turkish court and the European courts to emphasize the "civillity" of the Turkish women. Again, there is a rhetorically established equivalence between the two groups that is based not solely on gender but also on social rank. At the same time, I cannot help but remark on a lack of parity in the physical arrangements of the scene that Montagu describes. Standing in her riding habit, thoroughly covered from her jacket to her boots, she viewed the many Turkish ladies and their slaves, who reclined against pillows and sofas, indistinguishable in their nudity. Not only is there an evident contrast between Montagu's clothed, erect singularity and the reclining, generalized nudity of the Turkish women, but also Montagu is clearly the unassimilated viewer-writer of this scene. The subjective position she occupies is not unlike that of male poets who eulogize the body of the female muse or beloved, regarding her and enumerating her many beauties: "exactly proportioned," "their skins shineingly white," "their Beautiful Hair divided into many tresses hanging on their shoulders, braided either with pearl or riband, perfectly representing the figures of the Graces"

\footnotetext{
11It is this letter and its descriptions of the Turkish women's baths that is presumed to be the basis for Ingres's painting Le bain turc (1862). Several passages from this letter were found copied in Ingres's notebooks. Norman Schlenoff, Ingres, ses sources littéraires (Paris: Presses universitaires de France, 1956), pp. 281-83.
} 
(p. 324). Indeed, Montagu's reference to Milton's poetic descriptions identifies her through analogy as having powers and authorities that resemble those of the poet of Paradise Lost.

In another letter to Lady Mar, April 18, 1717, Montagu extravagantly praises the Kahya's lady, Fatima. Fatima becomes a good friend of Montagu's, and their visits are further described in other letters.

I was so struck with Admiration that I could not for some time speak to her, being wholly taken up in gazing. That surprizing Harmony of features! that charming result of the whole! that exact proportion of Body! that lovely bloom of Complexion unsully'd by art! the unutterable Enchantment of her Smile! But her Eyes! large and black with all the soft languishment of the bleu! every turn of her face discovering some new charm! . . . A behaviour so full of Grace and sweetness, such easy motions, with an Air so majestic yet free from Stiffness or affectation that I am perswaded could she be suddenly transported upon the most polite Throne of Europe, nobody would think her other than born and bred to be a Queen, thô educated in a Country we call barbarous. To say all in a Word, our most celebrated English Beautys would vanish near her. (p. 350)

Rhetorics of comparison are continued in this eulogy, for Fatima is said to be like a European queen, but she is also distinguished as being quite unlike European women in that her beauty far surpasses any European beauty: "Our most celebrated English Beautys would vanish near her." These comparisons that equate the European and Turkish court women may be understood as Montagu's further interventions in the male tradition of orientalism. If orientalism builds on and colludes with a discourse about women that divides and alienates different cultural groups of women from one another, Montagu's eulogy to Fatima's beauty represents a firm refusal to comply with this separation of occidental and oriental women.

Montagu's affectionate-and homoerotic_praise of Fatima's beauty also intervenes in the male discourse of heterosexuality that constructs divisions and hierarchies among women. In this letter and the letter about visiting the baths, Montagu's frank admiration for the physical beauty of the Turkish women underscores both situations as taking place in exclusively female society. Montagu's continual thematizing of the all-female context ironically invokes the orientalist topos of the female harem, and the specter of what Malek Alloula calls 
"oriental sapphism."12 In orientalism, the female harem, forbidden to male spectators and travelers, is invented as the site of limitless possibilities for sexual practices among women. But the harem is not merely an orientalist voyeur's fantasy of imagined female sexuality; it is also the possibility of an erotic universe in which there are no men, a site of social and sexual practices that are not organized around the phallus or a central male authority. Montagu invokes, in this sense, the topos of the female harem by means of her own homoeroticism as a powerful intervention in the male discourse of orientalism. As in the letter about the visit to the baths, however, it appears that Montagu is able to articulate her affection for Fatima only by means of the established literary tradition that exists for the praise and regard of female beauty, a male tradition of courtly love poetry exemplified by the sonnets of Shakespeare, Sidney, and Spenser. Following this literary convention, Montagu takes up a posture toward Fatima that still expresses love by means of an aestheticizing and anatomizing gaze. The viewer is taken by "that exact proportion of Body," and proceeds to praise the beloved's skin, mouth, and eyes, as Petrarch would evoke the unsurpassable beauty of Laura's features. Thus, Montagu's writings about Fatima and Turkish women are ironically divided and heterogeneous. On the one hand, Montagu frames the praise of Turkish women's beauty, independence, and manners as an intervention and a challenge to the male voyage writers' subordination of Turkish women. On the other hand, occasionally, and perhaps inevitably for the eighteenth century, Montagu articulates these interventions of praise by means of male literary and rhetorical models, such as courtly love poetry, which are not without their own methods of female objectification and subordination.

It is striking that Montagu's greatest divergences from the earlier tradition of travel writing consist of letters that describe Turkish women's society and the Turkish customs surrounding and affecting women, for in other letters her perceptions regarding Turkish culture are still not far from those of her male predecessors. For example, the letter to Anne Thistlethwayte (April 1, 1717) contains many statements

\footnotetext{
${ }^{12}$ Malek Alloula, The Colonial Harem, trans. Myrna Godzich and Wlad Godzich (Minneapolis: University of Minnesota Press, 1986), esp. chap. 9, "Oriental Sapphism."
} 
that coincide with the predominant British colonial discourse about foreign subjects. ${ }^{13}$ Here "London" and "this part of the World", are explicitly distanced and separated in a manner that is left uncontested throughout the letter. In addition, Montagu frames the descriptions of Turkish life as if they were theatrical entertainment for her English reader. She writes, "A Letter out of Turkey that has nothing extraordinary in it would be as great a Disapointment as my visitors will receive at London if I return thither without any raritys to shew them" (p. 340). She then proceeds to inventory in detail the bizarre and unusual animals found in Adrianople, including camels, asses, and buffaloes. The camels are described as "never thoroughly tamed"; the asses are "to me very ugly Creatures, their heads being ill form' $\mathrm{d}$ and disproportion'd to their bodys"; and the buffaloes are "all black with very short hair on their Hides and extreme little white Eyes that make them look like Devils" (pp. 340-41). The qualities of these "beasts," used for plowing, carrying, and caravaning, are contrasted with the swiftness and spirited elegance of horses, which "are not put here to any Laborious Work, nor are they at all fit for it" (p. 341). Indeed, Montagu characterizes the camels, asses, and buffaloes as lower species than the horse, and more physically suited to difficult labor.

I have a little white favourite that I would not part with on any terms. He prances under me with so much fire you would think that I had a great deal of courrage to dare Mount him, yet I'll assure you I never rid a Horse in my life so much at my command. My Side Saddle is the first was ever seen in this part of the World and gaz'd at with as much wonder as the ship of Columbus was in America. Here are some birds

${ }^{13}$ I have chosen not to discuss the entire question of the letters' addressees, their reception, and so on, for this would take me far afield from the focus of the chapter, namely, that orientalism overlaps with discourses of gender and class, and that these concurrent discourses may contest and displace orientalism. It is clear, however, that the different subject matters, as well as the treatment of those matters, in Montagu's letters must also be influenced by the addressees of the letters-their gender, class, occupation, and relation to Montagu. In this sense Montagu's letter to Alexander Pope, April 1, 1717, contains extensive discussion of classical literature, Turkish poetry, and the problems of translation, and the letter to Abbé Conti, May 17, 1717, a comparative discussion of the church and religion; whereas the letters to her sister Lady Mar address none of these subjects, dealing instead, as I have shown, with matters of female society-the customs, behavior, and dress-and the relation of Turkish female society to women in her own English society. 
held in a sort of religious Reverence and for that reason Multiply prodigiously: Turtles on the Account of the Innocency, and Storks because they are suppos'd to make every Winter the Pilgrimage to Mecha. To say the truth, they are the happiest Subjects under the Turkish Government, and are so sensible of their priveleges they walk the streets without fear and gennerally build in the low parts of Houses. Happy are those that are so distinguish'd; the vulgar Turks are perfectly perswaded that they will not be that year either attack'd by Fire or Pestilence. I have the happyness of one of their Sacred nests just under my chamber Window. (p. 341)

The world described in this letter is composed of an orderly chain of being ranging upward from beasts of burden, to birds, to horses, to Turks, to Englishmen. Just as the coarse "black" beasts of burden are contrasted with the "white" prancing horse, so, too, does Montagu's letter imply a distinction between the Turks, with their bizarre animal superstitions, and the English, with their more refined, rational tastes. Montagu's text accepts the topos of civilized culture as adherence to natural order and hierarchy; that she rides her horse sidesaddle is an emblem of the English command over and domestication of animals, while in contradistinction the "vulgar Turks" ("vulgar" being presumably a reference to their class as well as their cultural location) honor turtledoves and storks, granting them religious power, improperly elevating animals over humans. Not only does Montagu's portrait of the Turks' "unnatural" worship imply that they are less civilized than the English, but her descriptions of the natural hierarchy of beasts and horses might itself be understood to contain an allegorical defense of the "natural order" of colonialism. The colonial allegory is further dramatized in the image of Montagu's sidesaddle, which is viewed by a group of Turkish observers "with as much wonder as the ship of Columbus was in America." Finally, the characterization of storks as "the happiest Subjects under the Turkish Government" offers a metaphor of birds and humans that further allegorizes, and moralizes, the necessary and happy subjection of one group to another.

Just as Montagu's Letters occasionally resonate with the dominant British orientalist discourse, so the social context that produces The Turkish Embassy Letters-the diplomatic presence of Montagu's husband, Ambassador Wortley Montagu, in early-eighteenth-century 
Turkey-locates her text as part of England's colonial discourse about Great Britain's foreign commercial interests and colonies. For this reason it is appropriate to consider Montagu's Turkish Embassy Letters as part of the tradition of British travel writing about Turkey. Yet, quite evidently, Montagu's text occupies a dissenting position in the tradition; particularly on the questions of Turkish women's society and the treatment of women in Turkey, Montagu's Letters directly refute the perspectives, rhetorics, and themes of her orientalist predecessors' writing in that tradition. The conflicted relation of The Turkish Embassy Letters to orientalist travel writing - it is within the tradition yet critical of it-illustrates that orientalism does not make up a unified and dominant discourse, and that orientalist logic and statements often exist in a climate of challenge and contestation.

An emergent feminist discourse provides Montagu with the language, arguments, and rhetoric with which to interrogate traditional travel writing about the Orient while furnishing her with a critical position from which to write. Montagu's interventions in the orientalist tradition are primarily articulated in a feminist rhetoric and take place in the moments when her text refutes the constructed topos of the enslavement of Turkish women. In addition, a residual discourse about class and social rank supports Montagu's rhetoric likening Turkish and English court women; indeed, Montagu's praise of the civility, refinement, and politesse of aristocratic Turkish women may make use of this rhetoric of class identification even more than it expresses a belief in solidarity among women of different cultures. What I have characterized as.Montagu's shifting of the rhetoric of identification and differentiation is indicative of the location of her text at an intersection of orientalism, feminism, and representations of class and social rank. Montagu employs the rhetoric of identification between women of the Turkish and English courts as a means of intervening in the differentiating rhetoric of orientalism; the shift in rhetoric brings into conflict the figuring apparatus of orientalism and of discourses about gender and class. The contentious relationship between Montagu's text and the earlier travel writings concerning the subject of Turkish women illustrates that orientalism is not exclusively figured through an opposition of Occident and Orient, but figures itself through the formations of gender and class as well. It illustrates that distinct dis- 
courses may collude and overlap, but also, more important, that the crucial means for contesting and displacing one discourse may derive from the rhetoric and writing position of other concurrent ones.

\section{Voyages imaginaires: Lettres persanes}

The seventeenth- and eighteenth-century French tradition of travel literature contains its share of accounts that were the by-products of French colonial ventures in the Caribbean, India, West Africa, and North America, and missionary activities in China. ${ }^{14}$ These accounts can be considered analogues of the seventeenth- and eighteenth-century English travel writings discussed previously in this chapter. Yet the French tradition of orientalism differs from the English in an important respect: in the eighteenth century the French figure of the Orient is marked as a fictional site, and more elaborately drawn from a literary tradition. Whereas the English writings directly accompanied the British diplomatic and commercial contacts with the Turkish and Levantine Orient, the Orients of Montesquieu, Diderot, and Voltaire were more frankly imagined, more decidedly literary. The French figuration of the oriental harem as an exotic world of sexual and despotic license had a different status in French culture than Robert Withers's travelogue representation of the oriental harem did in England, owing to distinct national conditions, but primarily because the French conception of the Orient as Persia, Egypt, and the Ottoman Empire largely predated the extension of French colonialism to that

\footnotetext{
${ }^{14}$ Between 1630 and 1640, under Louis XIII, Cardinal Richelieu sought to build France's strength on the Continent by setting up a system of colonization through privileged companies. The Compagnie des Indes later built France's first colonies in India; the Compagnie des 100 Associés developed trade with Canada. Under Richelieu's command, merchants settled Martinique and Guadeloupe, St. Kitts, Grenada, the Grenadines, and St. Lucia; he sent pioneers to Réunion and l'Ile de Bourbon and reinforced colonies in Madagascar and Guiana.

Under Louis XIV Colbert developed Richelieu's colonial and trade policies. In 1664 he commissioned the Compagnie des Indes occidentales and the Compagnie des Indes orientales. The first was to settle both the Americas and the Caribbean; the second to colonize Madagascar and dominate trade with China. In 1670 he created the Compagnie du Levant to import silk and cotton from Asia Minor. Despite this limited trade with the Middle East, however, French colonialism during the seventeenth and eighteenth centuries focused on North America, Africa, and the Caribbean. It was not until 1798 that Napoleon's France attempted to colonize Egypt and other parts of the Middle East.
} 
region. The English travel accounts about the Orient accompanied the deepening of Anglo-Turkish diplomatic and commercial ties that began in the late sixteenth century under Queen Elizabeth I, but the French orientalism of the same period prefigured the more extensive French economic and military intercourse with the Middle East that began in the early nineteenth century under Napoleon Bonaparte, with the invasion of Egypt in 1798, and his efforts to establish a military alliance with Iran as an instrument of anti-British and antiRussian policies. ${ }^{15}$

This is not to imply, however, that France was not also gripped by the desire for empire and the mission civilisatrice. French colonialism in the Americas, in West Africa and the Caribbean, and to a smaller extent in India was well under way by the eighteenth century, and colonial ambition was piqued by continental competition as the French trailed the British and the Dutch in the struggle for empire under Louis XIV. In this sense, the literary figure of the Orient portended an as yet undeveloped relationship for France; the Orient became the French sign of desire for unconquered, uninfluenced territories in the context of a race for colonies among the European continental nations. Thus, in the French literature travel is allegorized to a greater extent-it is a geographic metaphorizing of the French nation's encounter with the non-French world-and the Orient is an imaginary figuration of ailleurs, of the au-delà. For France in the eighteenth century the Orient becomes the imagined site for the realization of colonial ambition.

At the same time, the travel literature of Diderot, Voltaire, and Montesquieu figured social elements that were marginal to, and that contested, the social structures of the ancien régime. ${ }^{16}$ There were

${ }^{15}$ On the importance of Napoleon's campaign in Egypt to the tradition of orientalism, see Said, Orientalism, esp. chap. 1, sec. 3. For an account of Napoleon's use of Iran for anti-British and anti-Russian policies, see Hasan-e Fasa'i, History of Persia under Qajar Rule, trans. Herbert Busse (New York: Columbia University Press, 1972).

${ }^{16}$ By ancien régime, I mean the feudal organization of old French society that prevailed roughly from 1600 to 1750 . The predominant economic base of the ancien régime was the rural agriculture economy. It was a rooted, stable society with very little or no class mobility or redefinition, society being organized in terms of the seigneurie - a group of landed estates owned and under the jurisdiction of the seigneur-and administered by the intendants, and the manses (tenured farms) worked by the mainmortables (serfs), peasants, or indentured farmers. During the seventeenth century 19.5 million, out of France's 20 million people remained bound to the land, plot, hut, cottage, or quartier where they grew up, according to Pierre Goubert, The Ancien Régime: French Society, 1600-1750, trans. Steve Cox (New York: Harper and Row, 1973). The old France was 
internal and external challenges to the stability of feudal Francenonaristocratic republican elements, antimonarchical forces, peasant revolts, the beginnings of small industry-which necessitated some migration and different roles for women and men, in addition to increasing continental competition from other colonial powers such as England, Spain, and Holland. In travel literature these pressures are registered and represented by and in the foreign space of an imagined Orient. Just as English novels based on the fiction of travel-such as Defoe's Robinson Crusoe (1719) and Swift's Gulliver's Travels (1726)portrayed England's internal social and political struggles in the displaced and imaginary locales of Crusoe's island, or the lands of the Lilliputians, Brobdingnag giants, and Laputans, so too did the eighteenth-century French voyages imaginaires become the means through which internal domestic challenges to social order could be figured and emplotted as foreign challenges, although it is apparent that the nature of the internal struggles was determined by different forces and factors in the English and French situations. Voltaire's representations of the social injustices of a thinly disguised ancien régime in the faraway worlds of Zadig (1747) and Micromégas (1752), or Montesquieu's wives, eunuchs, and oriental despots in the Lettres persanes, employ the theme of travel to signify the desire for empire, as well as to veil the more urgent preoccupations with the diminishing stability and coherence of the national culture itself. Thus, not only does the literary topos of travel express the French preoccupation with land and empire, but travel as a representation of imagined territorial expansion becomes an available discursive means of registering and regulating the domestic culture's concern with internal social differences and change during the ancien régime. ${ }^{17}$ In this sense both dominant and

characterized not by unrest, social mobility, and popular migration (as was the case by the mid-nineteenth century) but by stasis.

For a thorough demographic description of the ancien régime, see Goubert, L'Ancien Régime. Other studies of life during this period include Marc Bloch, Les caractères originaux de l'histoire rurale française, 2 vols. (Paris: Armand Colin, 1952, 1956); Fernand Braudel, Civilisation matérielle et capitalisme (Paris: Armand Colin, 1967); and Natalie Zemon Davis, Society and Culture in Early Modern France. Alexis de Tocqueville, L'ancien régime et la révolution (Paris: Michel Levy 1856), offers a political analysis of the ancien régime from the standpoint of the dismantling of its institutions after the French Revolution of 1789 .

${ }^{17}$ In a sense I am responding to a question posed by Louis Althusser in Politics and History: Montesquieu, Rousseau, Hegel, and Marx, trans. Ben Brewster (London: New Left 
emergent discourses of class and gender interrupt and disfigure the orientalizing genre of travel literature in France, as they do in Montagu's Turkish Embassy Letters. Yet the constellation, arrangement, and interplay of these discourses are quite different in the French instance than in the English example.

On one level Montesquieu's Lettres persanes is a text that proposes an orientalist structure in which Persia is the constructed opposite of France: the tyranny of the Persian harem contrasts with French representative government; the cruel instinct of the Persian master and his eunuch guards opposes French rationalism and law; and the confined chastity of the Persian wives counters the freedom and infidelity of French women. Composed of letters exchanged between two fictitious Persian travelers and their wives and eunuch guards at home, Montesquieu's text displaces internal French struggles into oriental characters and onto oriental spaces. The letters describe France from an invented "foreign" viewpoint of Persian travelers, and in this gesture they produce an Orient overtly fictionalized to elucidate the Occident they portray; the visitors, Rica and Usbek, record their observations of French social and political institutions, the church, the relations between men and women; interspersed among these letters are those that concern the intrigues and passions of the sérail (seraglio) that Usbek has left behind, providing a picture of the eunuchs' frustrations and the wives' ultimate revolt.

On another level, however, the text also offers a variety of challenges to this orientalist structure of opposition. The various means of "staging" Persia are exposed in Rica's letters, which thematize the theatricality and artifice of culture, and the "logic" of binary dependence and compatibility that informs the oppositional relationship between the French and the Persians is thus continually undermined.

Books, 1972), p. 75, at the point where he discusses Montesquieu's idea of depotism: "If the Persian does not exist, where does a French gentilhomme, born under Louis XIV, get the idea of him?" Depotism is Montesquieu's postulation of evil, lawlessness, the lack of order that continually threatens the structure of feudal monarchy; it is not based on knowledge of the Persian system of governance but is a representation of the perceived threats to social order, cloaked in foreign guise.

As Alain Grosrichard writes concerning the eighteenth-century concept of oriental despotism: "What makes it possible in effect to think the concept of despotism is less the reality of a political regime than the irrepressible part of the imaginary on which all political power rests. Despotism is the concept of a fantasm." Grosrichard, La structure du sérail: la fiction du despotisme asiatique dans l'occident classique (Paris: Seuil, 1979), p. 40. 
Most important, the binarism of Occident and Orient is ultimately challenged by the subplot of the wives' revolt. The relationship between the despot and his wives and slaves is not merely an emblem of the tyranny of a ruler over his subjects; it also emblematizes the very topos of orientalist domination. When this relationship is inverted by the conclusion to the novel, in which Usbek's wives successfully revolt against his rule, a number of different themes of mastery and rule are negated, including, most pointedly, that of orientalism itself. In this sense the dominant discourse of class hierarchy that figures the black and white eunuch harem guards as representations of the French intendants and nobility reinforces the orientalizing structure of the novel to the degree that the eunuchs never cease to be instruments of the master's power over the wives, or indeed to facilitate his power over the eunuchs themselves. In contrast, the emergent discourse of gender that portrays the wives as the revolutionary force that finally overthrows the master succeeds in challenging key assumptions and positions that are cornerstones to orientalism. Although the eunuchs' plot and the wives' plot develop and work together throughout the Lettres, they ultimately diverge and contradict each other as either plot supports or contradicts the orientalist themes.

The Lettres narrate the story of how a culture discovers and defines itself through imagined cross-cultural contact with a "foreign" Other. The fictional device that displaces the Persian travelers in France provides an occasion for a lively critique of French society on subjects as diverse as language, religion, law, education, sexual roles, and government; at the same time, the Persian criticisms of France reflect ironically on the invented oriental world from which they have supposedly come (this "Persia" itself being a thinly veiled metaphor for France). Rica's letters, in particular, are filled with this sort of selfreflexive commentary on French society, and in this sense they exemplify the orientalist logic that defines an eighteenth-century French world in terms of oriental otherness while critically commenting on the asymmetrical opposition of Persia and France. In lettre XXX, to his friend Ibben at Smyrna, Rica describes his reception by the inhabitants of Paris:

Lorsque j'arrivai, je fus regardé comme si j'avais été envoyé du ciel: vieillards, hommes, femmes, enfants, tous voulaient me voir. Si je sor- 
tais, tout le monde se mettait aux fenêtres; si j'étais aux Tuileries, je voyais aussitôt un cercle se former autour de moi. ${ }^{18}$

[When I arrived, they looked at me as though I had been sent from Heaven: old men and young, women and children, they all wanted to see me. If I went out, everyone perched at the windows; if I was in the Tuileries, I experienced immediately a circle gathering around me.]

Twentieth-century anthropologists have recorded similar experiences in which an ethnographer, crowded by staring "natives," enters another culture to do fieldwork. In the context of eighteenth-century Parisian society, Rica, the proto-anthropologist in Persian garb, is strikingly visible; he is marked by his difference, and his dress codes him as other, foreign, outré. "Enfin, jamais homme n'a tant été vu que moi" (In short, never was anyone as seen as much as I was), he writes (p. 104). He finds portraits of himself in Paris shops; his image is multiplied, distributed, and circulated everywhere. The Parisians' fascination with the exotic exposes a fascination with difference based on a preoccupation with defining sameness, an anxiety about the consistency and the cohesion of French identity in an age of rapidly mounting colonial ambitions. But paradoxically, although Rica is often, as letter writer, in the anthropologist's role of describing the French natives, he does not study their cultural otherness; rather he finds himself in the position of being the object studied by the Parisians.

Fittingly, when Rica decides to "go native," to give up his Persian clothing and to dress like a European, he finds he is ignored. "Libre de tous les ornements étrangers, je me vis apprécié au plus juste . . . car j'entrai tout à coup dans un néant affreux" (p. 105) (Free of all foreign ornament, I found myself assessed more exactly ... for all at once I fell into a terrible state of nonexistence). People no longer stare at him; he falls into oblivion. It is the cultural costume, the representation of difference, which is the French fetish. When someone announces that Rica is Persian, he reports: "J'entendais aussitôt autour de moi un bourdonnement: 'Ah! ah! monsieur est Persan? C'est une chose bien extraordinaire! Comment peut-on être Persan?' " (p. 105) (I would hear a buzz around me: "Oh! oh! Is he Persian? What a most extraordinary

${ }^{18}$ Charles Louis de Secondat, Baron de Montesquieu, Lettrespersanes (Paris: Gallimard, 1973), p. 104. All quotations are from this source. 
thing! How is it possible to be Persian?"). In this sense Rica's cultural difference is like a costume or mask that is attributed to him by French society. The Persian must assume the costume constructed for him or fall into nonexistence. As Rica is encircled by Parisian observers, his costume provides a mark of difference around which the Parisians can position themselves. Yet without his exotic garb, Rica cannot be objectified as Other. The circle has no central object, and the crowd lacks cohesion, perspective, and point of view. Without invented signs of visible otherness, sameness fails to locate itself. "Comment peut-on être Persan?" is indeed the question, for although it is possible to occupy the position of either the French or the exotic, the same or the different, it is not possible, within the world represented in the Lettres, to be other than either of the two categories of the opposition. Rica's only choices are visibility as an exoticized object that exists only in contrast to occidental orthodoxy or invisibility in his disguise as a Frenchman. In the world of the Lettres, the subjective presence of Persians is inconceivable; thus it is the paradox of his being Persian yet not being adorned as an exotic object that initiates the Parisians' incredulous query, "How is it possible to be Persian?"

Rica is a complex figure, for he is a central voice and authority who presents French customs, attitudes, and society, as well as an invented foreigner, the means through which the French text stages its critique of French culture. The paradox of Rica's authoritative position (as author of the letter) and his ultimate disempowerment (as masked fiction, as constituted Other) foregrounds the fundamental irony in Montesquieu's text. Rica's letter thematizes the use of the oriental in the process of French cultural identification and self-regard, and at the same time the letter is an example of this appropriation; it suggests that the Lettres persanes is not a simple orientalist text but more precisely a text that both discloses and comments on the eighteenthcentury French invention of the Orient. ${ }^{19}$ That is, the Lettres persanes does not simply "colonize" the oriental; the text also criticizes cultural appropriation by means of the manner in which it inverts and destabilizes the very categories of observer and observed, ruler and ruled, or

19Suzanne Pucci, in “Orientalism and Representations of Exteriority in Montesquieu's Lettres persanes," Eighteenth-Century 26 (1985): 263-79, also suggests that in its representations of exteriority the novel is a fiction about, rather than an example of, the European appropriation of the Orient. 
persan and parisien. The inversion of the Persians and the Parisiansthroughout a text that has as a very clear theme the identification of France through the discovery of its foreign Other-calls into question the orientalist binary logic on which the making of Others is founded. Furthermore, although a story of the Persians' cultural adaptation and conversion is being told, the epistolary form of the novel undermines the continuity of this familiar plot. Not only do the multiple perspectives of the letters disrupt any simulation of continuity or duration, but there are many lengthy digressions in the Lettres persanes that impede the progress of the conversion plot: the fable of the Troglodytes, the quotation of other letters within letters, the story of Zulema, and so on. Thus, the text represents a fiction in which the orientals Rica and Usbek are projected as being Other to the occidental, but the very process of this displacement is foregrounded and ultimately criticized by the irony and the epistolary nature of the text itself.

At the same time that the novel represents France from the "oriental" point of view, it also depicts an "oriental world" in the portrait of the Persian harem offered by the letters from Usbek's wives and the eunuch guards. These letters describe the intrigues and crises that take place in the harem during Usbek's absence. Thus, Montesquieu's novel of letters is often described as containing two parallel stories: one of Usbek's and Rica's travels to Paris, and the other of the despot's eventual loss of authority and the revolt of his wives in the harem. ${ }^{20}$ But even as the representation of the Persian world presents a French image of its cultural Other, it also allegorizes the problems and tensions of eighteenth-century France: the oriental despot is a figure for Louis XIV; the harem hierarchy of white and black eunuch guards is an analogy for the roles of the nobility and the intendants; and the wives in revolt are a figure for the peasantry during the regency of Philippe d'Orléans following Louis's death in 1715. In the sense that the first

\footnotetext{
${ }^{20}$ See, for example, Robert O'Reilly, “The Structure and Meaning of the Lettres persanes," Studies on Voltaire and the Eighteenth-Century 67 (1969): 91-131, and Aram Vartanian, "Eroticism and Politics in the Lettres persanes," Romanic Review 60 (1969): 23-33.

The notion of two stories should not be applied too literally, however. It is merely a critical device to allow the discussion of two different impulses in the novel, for the two stories are not so easily distinguished. Throughout the letters of Rica and Usbek, the two stories overlap and intersect at different junctures. For example, some of Usbek's letters to his wives and to the eunuchs can be considered as contributing to the "first story," others to the "second story."
} 
story-second story structure erects a binary relationship in which the oriental world is subordinated as a metaphor for French political problems, this binary relation is itself instrumental to the orientalism of the novel. But to the degree that the second story about the despot's overthrow interrupts and disallows a satisfactory closure of the portrait of foreign visitors in Paris depicted by the first story, the orientalizing structure is troubled and rendered more complex. Indeed, it is apparent that the heterogeneous conflicts invoked in the portrait of the harem bring a variety of narrative, logical, and rhetorical challenges to bear on the orientalism of the novel.

\section{Figuring Orientalism: Slavery, Marriage, Sapphism}

In the discussion of Rica's lettre XXX, I have suggested that the first story stages Persian culture as a means of commenting on French institutions and practices; this staging of Persia enunciates a binary relationship of complementarity between the French and oriental worlds that is characteristic of French orientalism, and in this sense the first story epitomizes the logic of the orientalist topos. But this binary logic is not restricted to the cultural opposition of France and Persia; it is reiterated by several additional figures invoked by the first story-in particular the institutions of slavery and marriage. During his stay in Paris, Usbek writes continually to his wives and eunuch slaves. In these letters the relationship between master and slave, as well as the marriage relationship between husband and wife, is represented as an emblem for despotism, or the absolute rule over one party by another. ${ }^{21}$ The relation between the despot Usbek and members of his harem appear in the first story as analogies for French political tyranny

${ }^{21}$ Despotism, in this sense, is the extreme tyranny of one over others. Montesquieu distinguishes despotism from democracy or monarchy: in a democracy, property and even relative wealth are guaranteed by the law; in a monarchy, the nobility and clergy are protected by a recognition of their privileges; but under despotism, there is no hereditary order, no nobility.

Grosrichard, Structure du sérail, p. 59, suggests that for Montesquieu, despotism is "the monster of monarchy," the internal possibility of disorder that may potentially erupt. "But then it stops being a specifically distinct form of government, and one might conceive of monarchy and despotism as being each a part of the other." In this sense despotism is the Other of the French political system, figured in the Orient of Persia. 
and rule, and are the principal vehicles for Montesquieu's attack on the despotic tendencies in the French system of government. Yet, if French rule is understood to extend to foreign territories under France, then the relationships between Usbek and his slaves and wives also serve as emblems of orientalism as colonial rule; in this sense the challenges to the institutions of slavery and marriage in the narratives of Usbek's declining rule and the wives' representations of female homosexuality in the harem provide implicit critiques of orientalism itself. The second story's narratives intervene in the first story's orientalism by complicating its binary logic of ruler and ruled with the more heterogeneous and multidirectional conflicts between the master, the eunuchs, and the wives, and by ultimately concluding the novel with the wives' triumph over the master.

Rica's and Usbek's letters about Parisian life are interrupted throughout by others from Persia: from friends, from various eunuch guards, and from Usbek's wives Roxane, Fatme, Zashi, and Zélis. These letters reveal that within the structure of the harem, a hierarchy exists in which Usbek dominates both the eunuchs and his wives; in his absence the wives answer to the eunuchs, who are the representatives of the despot's will. ${ }^{22}$ The eunuchs are enslaved by the master, and are commanded to exercise the master's power in his absence; yet they are essentially without their own power. In this sense their castration is a physical sign of their enslavement, and of their political impotence within the sérail. Just as the eunuchs feel sexual desire but lack the ability to act on this desire, so too do they have the illusion of exercising political power and yet, upon being commanded by the master, realize that they have no power of their own. In lettre IX, the Premier Eunuque offers to a friend Ibbi, a poignant description of his life in the harem:

Lorsque mon premier maître eut formé le cruel projet de me confier ses femmes, et m'eut obligé, par des séductions soutenues de milles menaces, de me séparer pour jamais de moi-même ... j'espérais que je

\footnotetext{
${ }^{22}$ The Lettres portray the harem as a hierarchical system, in which Usbek is master of the eunuch slaves, and the slaves control the behavior of Usbek's wives. Locating these relationships - of slavery and of sexual domination - in the oriental harem displaces the responsibility for these systems of oppression from France. The slave trade that brought West Africans to work for the French on the sugar plantations of the Caribbean islands, and the political and social inequality of women to men in eighteenth-century France, are concealed by this orientalist displacement.
} 
serais délivré des atteintes de l'amour, par l'impuissance de le satisfaire. Hélas! on éteignit en moi l'effet des passions, sans en éteindre la cause; et bien loin d'en être soulagé, je me trouvai environné d'objets qui les irritaient sans cesse. J'entrai dans le sérail, où tout $\mathrm{m}^{\prime}$ inspirait le regret de ce que j'avais perdu: je me sentais animé à chaque instant . . . pour comble de malheurs, j'avais toujours devant les yeux un homme heureux. (Lettres persanes, p. 62)

[When my first master conceived the cruel project of entrusting his wives to me, and had compelled me, by inducements backed by innumerable threats, to be forever separated from myself . . . I hoped that I would be free of love's seizures owing to my powerlessness to satisfy them. But alas! they eliminated the effects of my passion, but not their cause; and far from finding relief, I found myself surrounded by scenes which continually aroused them. On entering the seraglio, where everything made me regret what I had lost, I felt excited all the time . . . to my greater misfortune, I had a happy man permanently before my eyes.]

Within the structure of the harem, the domination of the slave by the master is sexually coded in the castration of the eunuch, literally forever separated from himself-"me séparer pour jamais de moimême." The eunuch's divided person, and his lack of sexual means, excludes him from the social institutions of marriage, family, and generation; in this way his sexual misfortune emblematizes a social and political impotence. ${ }^{23}$ Furthermore, as the eunuch's letter makes clear, the castration does not render him asexual; it does not eliminate sexuality and desire from his person. The eunuch is plagued by the

${ }^{23}$ The eunuch's social exclusion is a characterization of the political exclusion and impotence of the nobility, which began during the reign of Louis XIV and continued during the regency. Indeed, although L'esprit des lois was adopted by Enlightenment thinkers as liberal political philosophy, it must not be forgotten that Montesquieu wrote his critique of despotism from a position within a troubled and disenfranchised nobility. As Louis Althusser points out in Politics and History, Montesquieu had a very particular understanding of republicanism based on ancient models that placed "free men" at the forefront, and the multitude of artisans and slaves in the shade. He would have the people deprived of all direct power but grant them the right to choose representatives. Montesquieu did not want this "common people" (bas-peuple) to have power.

Althusser writes that "in denouncing depotism, Montesquieu is not defending against the politics of absolutism so much as liberty ingeneral as the particular liberties of the feudal class, its individual security, the conditions of its lasting survival and its pretensions to return in new organs of power to the place which had been robbed from it by history." Althusser, Politics and History, p. 83. Therefore, on the most overt level, the Lettres persanes moralizes: despotism is the sure road to popular revolutions. "Princes, avoid despotism if you would save your thrones from the people's violence," paraphrases Althusser (p. 85). 
memory of having once been whole and unseparated, and this memory is aroused by the company of the wives, and further by living with the fact of his master's continual satisfaction. In the harem world described in the Lettres, castration coexists always with an idealized memory of possession and power; it is the mark of a state of lack which is characterized by desire that can never be fulfilled. ${ }^{24}$

For the eunuchs, Usbek represents self-possessed masculinity and sexual identity. His political mastery is also symbolized by his sexual status, that is, by his noncastration, and by his sexual right to possess the wives. The apparent possession of himself and his wives creates Usbek's phallic role in the harem, but Usbek's mark of masculine potency, his "phallus," is purely symbolic; it is not denoted or determined by the mere presence of sexual organs. ${ }^{25}$ Rather, the phallus functions here as a socially constructed and conferred mark of masculinity, and is itself a signifier for the desire for masculine self-possession and its social and symbolic significance. ${ }^{26}$ In this sense, Usbek and the eunuchs alike desire phallic potency; absolute mastery and self-possession eludes them all. By placing Usbek away from the harem, and then recounting the story of his declining power and authority there, the novel further reinforces that even the master himself does not possess the phallus; his sexual and political rule is precarious, and he is no longer the principal authority around which the harem is organized.

${ }^{24}$ The desire for the lost state of wholeness may be a figuration of the aristocrat's nostalgia for the feudal estate and the untroubled autonomy of the noble classes during the ancien régime.

${ }^{25}$ Grosrichard argues, citing Ancillon's "Traité des eunuques" (Treatise on eunuchs, 1707), that traditionally eunuchs were organized into four classes, characterized by different degrees of physical castration: "those who were born such, those from whom everything was removed, those rendered sterile, and those types of men who were so unsuitable or of such a frigid temperament that they were incapable of procreating." Grosrichard, Structure du sérail, p. 190.

26I use the term phallus according to its development in the work of Jacques Lacan. The phallus is not the penis; it is the symbolic signifier of desire and the mark of subjectivity in that it includes within its definition both the desire for self-possessed subjectivity and its impossibility. In Lacan's rereading of Freud's oedipal process, the castration is symbolic and takes place when the subject is named and enters the social-linguistic field, identifying with the masculinity of the symbolic social arrangements and disidentifying with the femininity of the imaginary prelinguistic domain. In Lacanian theory no subject ever possesses the phallus; it is mythical, contradictory, and impossible. See Jacques Lacan, "The Agency of the Letter in the Unconscious, or Reason since Freud," in Écrits, trans. Alan Sheridan (New York: W. W. Norton, 1977). 
Despite the structure of the serail, which would seem to offer the despot absolute power, Usbek is portrayed in an increasingly vulnerable position as the novel progresses. Many of his letters betray a sense of geographic isolation and a suspicion that his rule is weakening at home. For example, in lettre CXIII Usbek writes about flux, change, and the eventual decay of life, as if he is anxious that even the most permanent structures may include their own destruction. He seems to suspect the decline of his authority in the harem even before the eunuchs report it to him. And in lettre CXIV an argument against the virtues of polygamy as a means for increasing population exposes Usbek's fears about not satisfying his wives. ${ }^{27}$ As early as the second letter Usbek is writing to the Premier Eunuque Noir in order to maintain his troubled rule over the harem. In other words, the novel begins with Usbek's rule endangered by his absence, and with his commands and threats to the eunuchs expressing an anxiety about his waning dominance.

Tu les sers comme l'esclave de leurs esclaves. Mais, par un retour d'empire, tu commandes en maître comme moi-même, quand tu crains le relâchement des lois de la pudeur et de la modestie.

Souviens-toi toujours du néant d'où je t'ai fait sortir, lorsque tu étais le dernier de mes esclaves, pour te mettre en cette place, et te confier les délices de mon coeur: tiens-toi dans un profond abaissement auprès de celles qui partagent mon amour; mais fais-leur, en même temps, sentir leur extrême dépendance. (p. 52; emphasis added)

[You should serve them (the wives) as if you were the slave of their slaves. But, by a reversal of authority, you are master of them like myself, whenever you fear a relaxation of the laws of chastity and modesty.

Always remember the nothingness from which I elevated you, when you were the lowest of my slaves, and that I put you in this post and entrusted to you my heart's delights: humiliate yourself profoundly before the women who share my love, but make them simultaneously aware of their absolute dependence.]

Usbek maintains his rule over the eunuch slaves through threats and reminders of their powerlessness; and by means of his control over the

27Usbek writes in lettre CXIV: "I think of a good Muslim as an athlete doomed to compete without respite, who is soon weakened and overcome by his initial efforts, and languishes on the very field of victory, lying buried, so to speak, beneath his own triumphs. ... It is to this state of debility that we are always reduced by the large number of wives we have, which is more likely to wear us out than to satisfy us" (pp. 259-60). 
eunuchs, he attempts to rule his wives. ${ }^{28}$ But even though the eunuchs are the executors of Usbek's will over the wives, they are indeed slaves, as Usbek is quick to remind them. In some ways they inhabit even lower rungs of the ladder of harem hierarchy because, under Usbek's orders, they must also serve the wives.

The slaves' impotence is signified not only by their castration but also by their lack of names; whereas Usbek, his friends, and his wives are all named in the letters, many of the eunuchs are referred to only by their rank and color (Premier Eunuque Blanc, Premier Eunuque Noir, and so on). The eunuchs themselves are not a homogeneous group of equal standing, for not only are there black and white eunuchs, but among these groups there are "first" and "second" eunuchs. Alain Grosrichard argues that the difference in color is also a mark of a division of labor in the harem: "The white eunuchs are the officers of the seraglio, and they command and administer according to a very strict hierarchy, or they serve as preceptors who look after the seraglio's children. The black eunuchs, on the other hand, specialize in guarding the harem; they watch over the entrances and exits. The white eunuchs flank the despot, doubling as his shadow. The blacks are at the sides of the wives, never letting them out of their sight." 29 This coded system of rank among the eunuchs-a highly competitive group among whom there is scarce and diminishing power to be shared by many-reinforces the parallel between the eunuchs and the nobility and intendants under the French monarchy.

The passage quoted from lettre II also establishes the analogy between the topoi of despotism and slavery and the relations of ruler and subjects, master and slaves. This analogy is enunciated by Usbek's use of the expression "un retour d'empire" to convey the sense of a transfer of command over the wives from Usbek to the eunuch. On the one hand, this expression signifies a shifting of power from Usbek to the eunuch-indeed, a "return" of power and masculinity to the castrated slave. But, on the other hand, "un retour d'empire" also carries the sense of a reversal of empire, a reversion of dominions to another rule, perhaps home rule. The power to command the wives is equated with the rule of territorial empire. Not only does the double valence of the

\footnotetext{
${ }^{28}$ Threats occur in other letters as well. For example, in lettre XXI Usbek writes to the Premier Eunuque Blanc: "And who are you but lowly instruments, which I can break at will; who exist only insofar as you know how to obey; who are only in the world to live under my laws, or to die as soon upon my order" (p. 87).

${ }^{29}$ Grosrichard, Structure du sérail, p. 185.
} 
expression convey Usbek's anxiety about the security of his rule-in that it portends the end of the novel where there is a reversal of authority and the "ruler" becomes the "ruled"—-but also the choice of the word empire reinforces an analogy with the themes of slavery and colonial rule.

The use of empire to describe the rule of the wives in the harem emerges also in lettre IX. After having described the frustration that results from his castration, the Premier Eunuque singles out one last source of pleasure:

Je me souviens toujours que j'étais né pour les [les femmes] commander; et il me semble que je redeviens homme, dans les occasions où je leur commande encore. ... Quoique je les garde pour un autre, le plaisir de me faire obéir me donne un joie secrète: quand je les prive de tout, il me semble que c'est pour moi, et il m'en revient toujours une satisfaction indirecte: je me trouve dans le sérail comme dans un petit empire; et mon ambition, la seule passion qui me reste, se satisfait un peu. (p. 63; emphasis added)

[I never forget that I was born to command them (the wives), and it seems to me that I become a man again on those occasions when I give them orders. . . . Even though I guard them for someone else, the pleasure of making them obey gives me a secret joy. When I deny them everything, it is as if I do it for myself, and indirectly it gives me satisfaction. The seraglio is for me like a small empire, and my desire for power, the only passion that remains mine, is to.some extent satisfied.]

Deprived of social and sexual status by his master, the eunuch is able to "become a man again" when he commands the wives. Several significant equations are contained in the eunuch's remarks. First, he echoes his earlier formulation that masculine station is provided and signified by the subordination of the wives; that is, possession of the phallus in the harem is essentially a socially conferred position. But in addition, for the eunuch in the absence of the master, the harem becomes for him "a small empire"; that is, the wives are equated with territories and masculinity is conflated with colonial rule. This portrait of the eunuch guard as petty oppressor, in which his own subjugation is converted into the will to subordinate the wives, renders the eunuchs as a class of people somewhat like the colonial French-the groups of settlers and military sent abroad, many of whom had been unprivileged commoners in France, but who were suddenly and ar- 
bitrarily powerful among the Caribbean, Canadian, and Indian populations over whom they ruled.

The eunuch's social exclusion, however, is often also interpreted as a characterization of the political exclusion of the nobility and intendants during the reign of Louis XIV, and continuing through the regency. But whether the Persian eunuch's plight is interpreted as an allegory for French colonials or for the noble and middle classes within French society itself, what is most notable about the figure of the eunuch is the discrepancy, the lack of signification, between the eunuch's "class" status and his actual access to power. The eunuch is the instrument of the master, with the ability to command the wives for him; but he also possesses less collective power and a less stable position with regard to the master than do the wives. For unlike the wives, who have some, if limited, social and sexual means of negotiating with Usbek, the eunuch has none. Furthermore, unlike the wives, the eunuch feels competitive with his fellow eunuchs, and he is not inclined to join with them-or with the wives-in revolt against the master; or perhaps in his singular impotence he is too attached to and dependent on the structure of the harem for social status. Despite his enslavement and subjection to the master's rule, he believes in the fiction of limited power he is granted over the wives; therefore he colludes with the master rather than objecting to his own enslavement.

Thus, the class tensions of French society become figured in the Persian harem in terms of the eunuch's castration, his rank in the hierarchy, and, most interesting, in terms of his relation to the master and his power over the wives. But if we note the textual conflation of masculine potency with imperial power, and consider the slavery of the eunuchs to be not only an analogy for despotic rule but a metafigure for colonialism or orientalism itself, then the degree to which the eunuchs accommodate the rule of the master is significant. It suggests that the class drama that is figured through the eunuch story never completely intervenes in or reverses the orientalist logic embodied in the master-slave relationship. Just as the eunuchs continue until the end to uphold Usbek's rule, and are not willing to disturb the structure of tyranny on which the harem is built, so too the narrative of the eunuch's dissatisfaction does not truly challenge the narratives of mastery, tyranny, or orientalism for which the topos of slavery stands. 
Although the eunuch plot complicates the binary logic and structure of the first story's orientalism, the narrative about slavery ultimately corroborates and sustains orientalism's logic and its figures.

The wives, like the eunuchs, are also subordinated by the harem structure and subject to the will of the master. Unlike the eunuchs, however, the wives revolt against Usbek, and the narrative about the wives' triumph reverses and intervenes in the binary logic of the novel's orientalism. The sexual domination of the wives by Usbek is first evident in the letters in which wives are characterized as property-"ornement," "trésor" - kept for the honor of the husband: "Qu'une femme est malheureuse ... ornement inutile d'une sérail, gardée pour l'honneur, et non pas pour le bonheur de son époux!" (p. 59) (How unhappy a wife is . . . a useless ornament in the seraglio, kept for the honor, not the happiness of her husband!), writes Fatme, one of the wives, to Usbek in lettre VII. Lettre XXVI, in which Usbek writes to his newest wife, Roxane, also reiterates the proprietary ownership of the wife by the husband; he characterizes the husband's right of sexual access to the wife as the "mastery of that treasure that you defended so steadfastly" ("pour me rendre maitre de ce trésor, que vous défendiez avec tant de constance!"; p. 95). In the world imagined in the Lettres, the Persian "marriage" is represented as the relationship emblematizing the mastery over women by men. As in Jean Dumont's New Voyage to the Levant, the oriental marriage is constituted as a sign for both the enslavement of women and the barbarism of the oriental world. In the Lettres, marriage also serves as a metafigure for orientalism itself.

Marriage, or the subordinated relationship of women to men, is a significant emblem of social hierarchies in general during the early eighteenth century. In the essays "The Reasons of Misrule" and "Women on Top" in Society and Culture in Early Modern France (1975), the historian Natalie Zemon Davis suggests that the festivals in which symbolic reversals of the sexual and social roles of women and men occurred constituted regular intervals of relief from the traditional order; these inversions were a social and cultural means of deferring actual disorder or real redistributions of power in family and political life. One implication of Davis's argument is that the relationship of men and women was, in this period, a privileged symbol of social hierarchy that came to represent a variety of hierarchical relationships: 
the relation of the colonial power to the colonies on the one hand, or of sovereign to citizenry on the other. In this sense the wives' actions at the end of Montesquieu's novel may have constituted a multivalent metaphor of rebellion that contributed to the postponement of actual revolutions to the degree that it figured a successful fictional revolution.

In the discussion of Usbek's relation to the eunuchs, I remarked earlier that Usbek's letters express his evident anxiety about the security of his rule at home. But the sense of the precariousness of his rule is even greater in terms of his relations with his wives. In lettre XXVI Usbek attempts to reestablish his authority over Roxane by renarrating the tale of his physical pursuit of her during the early days of their marriage:

Deux mois se passèrent dans ce combat de l'amour et de la vertu. Vous poussâtes trop loin vos chastes scrupules: vous ne vous rendîtes pas même, après avoir été vaincu: vous défendîtes jusqu'à la dernière extrémité une virginité mourante: vous me regardâtes comme un ennemi qui vous avait fait un outrage, non pas come un époux qui vous avait aimée. . . . Je n'avais pas même une possession tranquille; vous me dérobiez tout ce que vous pouviez de ces charmes et de ces grâces; et j'étais énivré des plus grandes faveurs, sans avoir obtenu les moindres. (pp. 95-96)

[This struggle between love and virtue lasted two months. You carried the scruples of chastity too far: you did not surrender, even after you had been conquered; you defended your dying virginity to the very end; you considered me an enemy who had inflicted an outrage on you, not as a husband who had loved you. ... I did not even have a tranquil possession of you: you deprived me, as far as you could, of your charms and your grace, and I was swooning from the greatest favors, without having obtained the lesser.]

In Usbek's narration of the consummation, Roxane first attempts to stab him, and then for the succeeding two months resists his advances. After the physical penetration takes place, she still does not surrender, but defends her "virginite mourante" until the end by withholding her own desire. In Usbek's retelling, Roxane's terror is evident, yet she appears to have practiced one potent form of resistance: what Usbek wants to construe as Roxane's modesty is her means of refusal. To disallow Usbek "une possession tranquille," to 
refuse willing or passionate participation, is her only weapon of resistance. As if acknowledging his lack of total possession, in lettre XXVI Usbek substitutes a narrated conquest of Roxane for the actual conquest he has never attained. In the novel's final letter, lettre CLXI, written during the wives' revolt, Roxane articulates this means of resistance to Usbek. She declares that although she submitted to his physical demands, she had always withheld herself and had sought her pleasures elsewhere; she is triumphant in announcing her deceptions and betrayals: "Oui, je t'ai trompé; j'ai séduit tes eunuques; je me suis jouée de ta jalousie. . . . Comment as-tu pensé que je fusse assez crédule pour m'imaginer que je ne fusse dans le monde que pour adorer tes caprices?" (p. 350) (Yes, I deceived you. I seduced your eunuchs, outwitted your jealousy. . . . How could you have thought me so credulous as to imagine that I was in the world only in order to worship your caprices?]. Roxane ultimately escapes Usbek's tyranny by articulating her dissimulation, displacing his assumptions that she has always been his possession.

Lettres CXLVII through CLXI record the story of the revolt: the eunuchs' letters report the wives' growing defiance to Usbek; Usbek's letters order the guards to stop the transgressions and order his wives to obey; ultimately, the wives' letters to Usbek refuse to recognize his authority and declare their independence from him. The wives' acts of rebellion include quarreling, disobeying the eunuchs, and indulging in gaiety and infidelity; but the transgressions most forcefully condemned in the eunuchs' reports to Usbek are the implied erotic relationships between the wives and their female slaves. In both lettres IV and CXLVII female homoeroticism is introduced as one of the most serious violations of the rules of the harem. Usbek's wife Zéphis writes to him to ask that her slave Zélide not be taken from her. She alludes to the eunuch's reports of illicit homoeroticism, and offers an explanation of the eunuch's suspicions:

Il veut, à toute force, m'ôter mon esclave Zélide, Zélide qui me sert avec tant d'affection, et dont les adroites mains portent partout les ornements et les grâces. Il ne lui suffit pas que cette séparation soit douloureuse; il veut encore qu'elle soit déshonorante. Le traître veut regarder comme criminels les motifs de ma confiance: et parce qu'il s'ennuie derrière la porte, où je le renvoie toujours, il ose supposer qu'il a entendu ou vu des choses, que je ne sais pas même imaginer. (p. 55) 
[He is determined to take my slave Zélide away from me, Zélide who serves me so affectionately, and whose deft hands perform beauty and grace everywhere. It is not enough for him that this separation should be painful; he wants it to be dishonorable as well. The brute wants to regard the motives for my trust as criminal; and because I always send him outside the door and he gets bored, he dares to assume that he has heard or seen things that I could not even imagine.]

Zéphis's letter not only registers that female homoeroticism is regarded as a most serious transgression of harem laws, but it also provides an analysis of how that transgression is constituted. Zéphis's explanation of the eunuch's accusations suggests that female homosexuality has a history in the cultural text and imagination of the harem: whether as a pleasurable fantasy for voyeuristic eunuchs or, conversely, as an imagined threat to the master's rule and to the structure of the harem, the topos of sapphism already exists as a constructed opposition to the required licit heterosexual fidelities of the wives that sustain the harem hierarchy. Furthermore, in emphasizing that the eunuch is always kept outside the door, she implies that he has particular motives for fabricating his accusations. As lettre IX records, the eunuchs feel continual frustration-placed as they are among the women they desire yet cannot touch, and in the shadow of the master's satisfaction and his access to the wives, which the eunuchs envy. The imagined locus of female homosexuality-a site that the eunuchs are forbidden to enter or even to gaze into-is the perfect emblematic figure for the eunuch's frustration, and for his castration. Finally, the possibility, whether practiced or imagined, of a nonheterosexual female society not organized around the master's phallus threatens the ultimate subversion of the institution of marriage and fidelity to the master so essential to the structure of the harem. The eunuch's accusations against Zéphis and Zélide, and his insistence on separating the two women, illustrate the powerful force of this specter on the imagination of those most invested in, and dependent on, the harem structure.

Therefore, at a later point the reported incident of one of the wives, Zachi, sleeping with her slave fills not only the eunuchs but also Usbek with panic and dread. They believe that the acts and practices they previously had only imagined have come to pass; it is the beginning of the end. In lettre CXLVII the Grand Eunuque reports to Usbek: 
Les choses sont venues à un état qui ne se peut plus soutenir: tes femmes se sont imaginées que ton départ leur laissait une impunité entière: il se passe ici des choses horribles. . . .

J'ai trouvé Zachi couchée avec une de ses esclaves, chose si défendue par les lois du sérail. (p. 337)

[Things have arrived at an unendurable state of affairs; your wives have come to think that your departure meant complete impunity for them. Horrible things are happening here. . . .

I found Zachi in bed with one of her slaves, which is absolutely forbidden by the laws of the seraglio.]

The "choses horribles" he reports would seem to refer to homosexuality among the wives. But the acts themselves remain unspecified as if to allude to sexual excesses in general: "a universe of generalized perversion and of the absolute limitlessness of pleasure," as Malek Alloula describes the locus of the seraglio in orientalist literature. ${ }^{30}$ That is, the reporting of "choses horribles" may be purposefully ambiguous so as to allude to a variety of unnamed things-not only forms of female sexuality that are neither dependent on nor organized around men but also the possibility of other sexual acts and practices that are unimaginable, deviant, polysexual, which also break the laws of the sérail.

Thus, the figure of sapphism-constructed as the most powerful threat to the sexual economy of the harem-is instrumental to the masculine discourse on the necessary discipline and containment of the wives. In her final letter to Usbek, however, Roxane reappropriates this figure of female homosexuality and through it articulates the power of the wives' rebellion. She declares in lettre CLXI that she has confounded and "remade" the harem laws, alluding to the sign of sapphism to deliver the last potent blow to Usbek: "J'ai su, de ton affreux sérail, faire un lieu de délices et de plaisirs. ... Non: j' ai pu vivre dans la servitude; mais j'ai toujours été libre: j'ai reformé tes lois sur celles de la nature; et mon esprit s'est toujours tenu dans l'indépendance" (p. 350) (I knew how to turn your terrible seraglio into a place of delightful pleasures. . . . No: I may have lived in servitude, but I have always been free. I have reformed your laws according to the laws of nature, and my mind has always remained independent). In announcing to Usbek that she has remade his laws according to "celles de la 
nature," Roxane ventures an ironic reversal that renders the wives' diverse pleasures among themselves as natural while the supposedly licit heterosexual fidelity that is demanded of the wives is cast as unnatural. ${ }^{31} \mathrm{Her}$ proclamation of having remade the harem into "un lieu de délices et de plaisirs" alludes to the notion of sexual transgressions among the wives, knowing this to be a powerful weapon against Usbek. As if to goad his imagination further, she stops short of specifically naming these acts and pleasures; the specter of female homosexuality may be even more powerful when it remains unnamed. Her defiguring of the topos of marriage reminds him that the husband's hold over the wife is a wholly uncertain one. The revolt of the wives, with its images of female transgression, ends the novel; Roxane has the last word, and her statement of her independence and the failure of Usbek's authority are the final motifs of the novel.

In this sense, although the novel may conform to a logic that constitutes Persian tyranny as the opposite of French rationality, this orientalist binarism is challenged in several ways. On one level, the fictional device of placing Usbek and Rica in Paris inverts the roles of persans and parisiens, and throughout the novel the allegorizing of the French court in the oriental figure of the harem parodies the orientalist logic. On another level, orientalism as despotic and colonial rule is thematized in the domination of the eunuch slaves, the wives, and the female slaves in the harem, and is thus further challenged by the inversion of hierarchy that results from the wives' rebellion. The narrative conflicts of the Persian harem plot disrupt the binary logic of this orientalist projection, recasting the initial orientalism of the novel. As I have suggested, however, the heterogeneous class and gender narratives bear different relationships to the orientalist framework. Although the class narratives that figure the French nobility and intendants in the harem eunuchs compete with the orientalist narrative of the novel, in portraying the eunuchs as remaining loyal to the master,

\footnotetext{
${ }^{31}$ Roxane's declaration of her ultimate freedom from Usbek's mastery, and of her own sources of pleasure, echoes an earlier statement by Zélis in lettre LXII: "However, Usbek, don't imagine that your present situation is happier than mine. Here I have enjoyed countless pleasures unknown to you. My imagination has worked continually in order to realize their value. I have lived while you have stagnated. . . Although you keep me imprisoned, I am freer than you" (p. 161). Both Roxane and Zélis taunt Usbek that they have invented other means of pleasure-pleasures he could not offer them and to which he does not have access.
} 
the class narratives do not displace the topoi of either despotic rule or, ultimately, orientalism. The eunuchs bitterly feel the suppression of their potency and power by the master, yet they inevitably comply with Usbek's rule by attempting to administer the wives, as the French nobles and intendants ultimately taxed and administered the peasantry. Yet the gender narrative that represents peasant unrest in the wives' anarchy challenges the theme of rule by portraying the wives as victors over the master's tyranny. The final images of the novel are of an exclusively female community not organized around a male authority or symbolic phallus. The wives' plot is not only a dramatic representation of female challenges to a patriarchal system but also a narrative of peasant class struggle figured in terms of female sexuality and gender. If we accept the harem as a metaphor for orientalism as colonial rule, then the wives' revolt constitutes a gendered narrative critique of that topos of rule. Thus, in Montesquieu's Lettres persanes, as in Montagu's Turkish Embassy Letters, the tensions between orientalism and the numerous challenges from competing narratives demonstrate that orientalism is not univocal or discrete but rather that orientalist logic often exists in a climate of challenge and contestation from other distinct yet intervening narratives. 